\title{
A world turned upside
Social hierarchies and a new history of egalitarianism
}

Elizabeth Anderson traces the history of egalitarian ideas as they have grown out of grassroots movements focused on overcoming entrenched social hierarchies. In reply, Ben Jackson and Anne Phillips engage with this relational account, particularly in a British context where distributional concerns are high on the political agenda.

Egalitarianism today is usually taken to refer to a set of views about the just distribution of income, wealth and other goods. But this view unduly narrows the egalitarian agenda, which is broader than matters of distributive justice alone. In this essay, I chart how egalitarian ideas have developed from social movements whose primary interest has been forging a society of equals and battling against social hierarchies. ${ }^{1}$

\section{THE LEVELLERS AND A SOCIETY OF EQUALS}

Many forms of egalitarianism have taken something other than distributive justice as their starting point. The feminist movement is plainly egalitarian, seeking reproductive freedom for women, yet for women there is nothing that is being distributed equally in this case. LGBT activists seek the freedom to appear in public without shame or stigma. Activists in the American civil rights movement of the 1960s sought racial integration of schools, explicitly in repudiation of the doctrine 'separate but equal' merely having equal resources was not enough. All of these movements are egalitarian, but their demands cannot always be captured in terms of equal distributions of income, resources, wealth or other goods. And I could give many more examples of the same sort.

So what are they after? They strive for a society of equals: a society in which people relate to one another as equals, whether it is in their dayto-day interactions, across the major institutions of government, or in the workplace. This is a relational ideal which can be traced all the way back to the Levellers of the English civil war period, who represent the first recognisably egalitarian sociopolitical movement.

Much earlier in history, perhaps even with the birth of monotheistic religions, we see claims of the fundamental moral equality of souls - for instance, that all human beings are made in the image of God and are equally eligible in principle for salvation. Indeed, moral claims to equality are deeply rooted

1 This essay and the responses to it are based on a talk given by Professor Anderson at IPPR on 13 June 2013. An audio recording of the event is available at https://soundcloud.com/ippr/a-history-of-egalitarianism. 
in the history of the three leading monotheistic religions today. However, if we see how that claim of moral equality actually played out, particularly in the history of Christianity, it had essentially no translation into social or political change. Equality was for the next life - in salvation, the souls would all commune with each other on equal terms, but not in this world. In this world, a kind of social hierarchy is needed to preserve social order, and all kinds of reasons were offered to justify various forms of social hierarchy, including slavery, serfdom, patriarchy, monarchy and lordship.

It is also the case that early in human history we find communities of people living on terms of equality with one another. Usually these are ascetic religious communities like the Essenes. But their renouncement of wealth for material equality was not done out of any political convictions about equality, rather for the sake of holiness.

The Levellers, however, represented something distinctly new. For them, egalitarianism was a claim to social and political equality that was based on an assertion of the basic moral equality of human beings. The idea that we can translate the fundamental moral equality of human beings into matters of social and political policy for this world, that our moral equality grounds and justifies the establishment of the society of equals - these claims were first made at the time of the English civil wars.

What were the Levellers levelling? They were not engaged in a project of distributive justice as we would understand it today. In economic terms they were interested in removing monopoly: for their time, they were free-traders, although that also had a very different significance in the 17th century. Politically, their agenda was that of a universal male franchise - 'one man, one vote' - with representative districts of equal population, abolition of the lords' privileges, the rule of law, and equality before the law, with laws passed by the House of Commons being equally valid for lords and commoners. Essentially, they were criticising the social hierarchy - this is what they were levelling.

\section{DISMANTLING SOCIAL HIERARCHY}

Levelling social hierarchies is at the root of all egalitarian movements.

Sometimes that takes a fundamentally distributive focus, but if you see what unites all egalitarian movements - such as feminism, the struggle for racial equality and for the rights of people of different sexual orientation - it is a critique of social hierarchy and an aspiration to realise a society of equals, a society in which all citizens meet each other face to face with mutual respect and cooperation. The history of egalitarianism is the history of attempting to dismantle, or at least tame, social hierarchy. It is a history of experiments in living that seek to replace social hierarchy with relations among equals.

"The history of
egalitarianism
is the history of
attempting to
dismantle, or at
least tame, social
hierarchy."

Here I am defining social hierarchy in a particular way. It consists in durable group-based inequality that is sustained by systematic laws and habits. Every so often you hear, 'well as long as the groups are grouped by ability then hierarchy is acceptable'. Yet one of the deep strands of critique emerging from the egalitarian movement is that meritocracy itself is an inherently unstable formation. Once people get to the top, they 
want to ensure that their children receive the same privileges. And so meritocracy has systematic, inherent tendencies to resolve and reproduce itself along lines of group identity that are usually defined in ancestral or genealogical terms.

There are three kinds of social hierarchy that egalitarians have historically been worried about, and considering these helps to expand our vision of what an egalitarian agenda looks like.

The first kind is hierarchies of domination and subjection. This is where some groups of people order other groups around, and where subordinates are powerless to hold their superiors accountable for the way they are being treated. The extreme case is slavery. Indeed, abolitionism was a major focus of egalitarianism. It is possible to be an abolitionist without being an egalitarian, but there were radical abolitionists who strongly advanced egalitarian agendas, particularly in the US and also in the connections between abolitionism and Chartism. In England, there was a move from the critique of slavery to the critique of wage slavery - not just chattel slavery, but all kinds of arbitrary subordination in the workplace.

The second hierarchy is of esteem. In this case some groups are stigmatised, ostracised or treated as pariahs on the basis, for example, of class, race or disability.

The third hierarchy is of standing. This occurs when, in deliberation and decision-making, some interests count more than others. We all make decisions, but the state makes decisions that dramatically affect the interests of others. Some people's interests are taken into account while others' are radically discounted or perhaps neglected altogether.

There is an important link between hierarchies of standing and distributive justice. The state constructs the fundamental rules of property and contract, taxation, inheritance and so forth. It can configure these rules and institutions in ways that treat everyone as being of equal importance, or it can slant and shape our distributive rules so as to favour certain privileged groups. Whether the rules underpinning distributive justice are set in an egalitarian way is dependent on the prevalence of hierarchies of standing.

\section{EGALITARIAN THOUGHT AND SOCIAL MOVEMENTS}

My assessment of the history of egalitarianism also demonstrates that egalitarian social movements are the source of egalitarian ideas. These are then picked up by intellectuals, theorists and thinktanks, and are reworked with empirical support and more systematic theorising. Nonetheless, time and time again, we see creative thoughts bubbling up from the movements themselves. Hence, egalitarian thought has flourished when egalitarian social movements have flourished, and has tended to stagnate when the movements themselves are in periods of weakness or uncertainty.

This link between social movements and the development of ideas has other important implications. Egalitarians are constantly learning and developing in a pragmatic way. Egalitarianism means different things at different points in time, for different movements engaged in different

"Whether the rules
underpinning
distributive
justice are set in
an egalitarian way
is dependent on
the prevalence
of hierarchies
of standing."

"Whether the rules underpinning distributive justice are set in an egalitarian way is dependent on of hierarchies 
struggles. In part this is because a lot of what is happening in egalitarian social movements is - as we have already described it - 'experiments in living'. Sometimes the movement is triumphant and wins a victory, achieves some item on its agenda, and it seems for a moment that everything is settled. But what is often discovered is that this not true, that the initial problem is not settled at all.

A classic case of this is abolitionism in the US. At the point when slavery had been abolished with the enactment of the 13th amendment towards the end of the civil war, people were not sure what they had in fact abolished. This was because of the new labour regime that had been rapidly established for the freed people. This regime, while not a kind of chattel slavery, in that no one could be bought or sold on the auction block and families could not be sent to different plantation owners, was nevertheless extraordinarily oppressive. In many respects it was barely different from the slavery regime that had preceded it. People came to realise that the conditions of labour had to be thought through again. In the US context, that thinking was absolutely critical in motivating the labour movement. Indeed, the freed people were some of the earliest workers to organise, go on strike and revolt against oppressive labour laws.

The abolition of slavery provides just one example of a movement achieving a major item on its agenda only to see that social hierarchy is endlessly creative. The work of egalitarianism is never done because social hierarchy is resourceful: it always has new ways of reconstituting itself. New agenda items have to be developed in response to this.

This continued reinvention needs to respond to contemporary concerns as well. Egalitarians today should think back to the Levellers, and in particularly to their distinctively republican concern for hierarchies of domination and subjection.

In the US, as the labour union movement has faded into virtual nonexistence in the private sector, we see a dramatic and highly aggressive reassertion of arbitrary domination of workers. Many American workers have no privacy in the workplace, no freedom of speech; they can be fired for expressing political opinions or for speaking a different language from the one approved by the boss. Outside of work, in most of the 50 states, workers can be and are sanctioned for their choice of domestic partner, for their political views, even for the way they dress. These forms of domination still exist today, and in the absence of a vibrant labour movement in the US there is a need for egalitarian thinking that has a wider agenda than just distribution. The left must revisit the rich tradition of social movements and ideas which took as their key goal the dismantling of social hierarchies.

\section{RESPONSE: BEN JACKSON, LECTURER IN MODERN HISTORY, OXFORD UNIVERSITY}

I wish to focus on how Professor Anderson's history of egalitarianism relates to the traditions of egalitarian thought that have played a role in British political history, traditions which continue to play a role in the debates that currently preoccupy the British left.

\section{"The work of egalitarianism is never done because social hierarchy is resourceful: it always has new ways of reconstituting itself."}


Equality has always been central to the identity and rhetoric of the British left, and the Labour party in particular, but there has always been a lively debate about exactly what a commitment to equality means and what it entails. Anderson's arguments can help us to get a handle on some of these questions. In this response, I will make three points.

The first point is about the distinction between relational and distributive equality. Anderson emphasises a vision of equality that is focused on social relations. By this account, the egalitarian aim is to replace social hierarchy with an equality of social standing so that people relate to each other as equals in the social and civic spheres. She contrasts that with what might be thought of as a kind of pure distributive theory of equality that is about the distribution of goods.

There is much in this social relational vision that resonates with the history of egalitarian thought on the British left. For instance, the severe hierarchies of social status that were generated by the class system were a key preoccupation of classic egalitarians such as $\mathrm{RH}$ Tawney. In his seminal 1931 book Equality, he criticised employers for developing what he called 'an extraordinarily overbearing tyrannous and irresponsible habit of mind' which regarded workers as servants and promoted the idea that people are productive tools. The privilege and tyranny, as Tawney saw it, generated by class inequality created a spirit of domination and servility.

In this connection, we can also think about George Orwell's Homage to Catalonia, in which he gives a very evocative description of what life was like in Barcelona during the Spanish civil war under the republican regime. He said that it was a city of rough economic equality and, as a result, it was a city in which social relationships were equal. The example that Orwell gave was that workers looked you in the face and greeted you as an equal. Servile and even ceremonial forms of speech had temporarily disappeared. In republican Barcelona, Orwell said, he had breathed the air of equality.

This gives us the flavour of the sort of egalitarian vision that Anderson is describing. However, importantly, there was a significant connection between distributive and relational equality in this tradition. The hierarchies of status and injuries to self-respect that these writers and activists opposed were in their view chiefly due to factors such as the nature of the workplace, the distribution of income and wealth and the places in which different social classes lived. What is more, egalitarians in this tradition cared about distributive inequality for other reasons as well - they were also concerned about the overall justice of material distribution as an independent matter.

My question for Professor Anderson is whether she has definitively to choose between distributive and relational equality? Or would we not want an account of the history of egalitarian social movements which says that they were animated by both distributive and relational concerns? There might then be a larger historical issue here as well. If Anderson is saying that all egalitarian movements in the past have been relational and that there was not much distributive egalitarianism in a strict sense, until the
"In republican

Barcelona, Orwell said, he had breathed the air of equality. Servile and even ceremonial forms of speech had temporarily disappeared." 
vogue for distributive egalitarianism among contemporary political theories, then that would be a strong historical claim.

The second point I want to make requires us to fast forward from Tawney and Orwell to Tony Blair. During the New Labour years, there was a rather unsatisfactory debate about whether Labour in government should pursue equality of opportunity rather than equality of outcome. An emblematic moment of this debate was when Blair famously refused to say that he was troubled by the earnings of those at the top; he specifically mentioned the earnings of David Beckham in an interview with Jeremy Paxman and firmly refused to say that he thought it was wrong that some people were earning too much money. For egalitarian-inclined people, like me, this was Blair's tipping-point moment.

The debate in the Labour party about inequality at the top has moved on quite a long way since that interview, not least because there is now a sense that the extravagant share of earnings enjoyed by the richest has played a damaging economic role in squeezing the incomes of middle and lower earners.

But what would Professor Anderson's view be on Blair's argument? In some of her earlier writings on equality, particularly her article 'What is the point of equality?' you could say that she has been attracted by a view not identical but similar to that of Blair. This is in the sense that in her writing she suggests that the most important distributive aspect of inequality to attend to is to provide a high enough minimum standard for the worst-off in society. Her contention is that everyone should receive enough to enable them to exercise democratic citizenship and to meet others as equals.

One question that arises, then, is what we should think about inequalities above that minimum threshold. Should we be intensely relaxed about people earning lots of money, provided that everyone has their minimum citizenship protected? To what extent are relational egalitarians concerned about reducing inequality at the top end or about providing a minimum standard? An alternative reading of Anderson's view is that she does have a set of reasons for why we might care about inequality at the top; clearly, if the very rich end up exercising excessive influence on politics and becoming a privileged social elite then that would be of concern for a relational egalitarian.

My third point concerns the political value of contemporary philosophy. Professor Anderson contrasts her view of equality with the dominant ideas articulated in contemporary analytical philosophy. However, as a historian, I see a potential danger in downplaying the philosophical and political importance of this body of work.

Of course, philosophers only rarely change the world in any fundamental sense, and it would be unrealistic to expect too much from academic philosophers, but the prominent place that has been occupied in recent philosophical debates by figures like John Rawls, Ronald Dworkin or Gerry Cohen is of some significance. Philosophically, the work that was done in the analytical tradition has been quite important in clarifying the concepts and principles that underpin egalitarianism; we understand a lot more 
about egalitarianism as a result of that work. Politically, the strength of their commitment to egalitarian values has also been important ballast at a time when egalitarian values have come under relentless attack from the right.

In the last 20 or 30 years, the hardest equality issues to think about and win on politically have been claims to egalitarian distribution, whether we think of egalitarian distribution as an objective in itself or as a means to other relational egalitarian goals. The analytical tradition of writing about equality has been quite important in keeping the flame of economic equality alive. This has been a time when, as Anderson has said, the labour movement has been pulled apart and pushed to the right, and when the dominant social discourse about economic inequality has an unreflective ideal of meritocracy. The discourse within the analytical tradition could be seen as a political resource for the critique of those kinds of trends. This is another reason why we might not want to set up too stark an antagonism between the relational account and contemporary analytical thinking about equality.

\section{RESPONSE: ANNE PHILLIPS, PROFESSOR OF POLITICAL AND GENDER THEORY AT THE LONDON SCHOOL OF ECONOMICS}

I really appreciate the way that Professor Anderson is restoring the connection between equality and democracy: not just the emphasis on equality being about domination and power differentials, but also the other side of that - democracy being primarily about equality.

There has been a real shift in the way people think of democracy. They think too much in terms of the mechanisms of democracy: accountability, decision-making, competitive party elections. All of these things are of course very important, but as a system of accountability or a way of regulating corruption democracy has not actually been terribly impressive. There are very few democracies that have lived up to the kind of ideals that one might have hoped for.

However, if you step back from these mechanisms and details and think about what is entailed in saying that all of us - regardless of class, sex, ethnicity, sexuality - actually have exactly the same standing in relation to the decisions that are supposed to govern our lives, it seems to me that this is the most amazing thing. The idea that societies would have come to that kind of view and committed themselves to the idea of that kind of democracy, even if they don't practise it, is an astonishing achievement.

You hear people in the tradition of political theory and science almost debating whether equality is a crucial component of democracy, or if democracy is primarily defined by other things. That seems to me to be deeply problematic, so one of the things that is important about what Anderson has said is about not just restoring the power issues to equality but also restoring the equality issues to democracy.

The other very positive thing is Anderson's focus on inequalities and hierarchies between groups rather than between individuals. This has been one of the real problems in the recent philosophical literature on equality. It has become caught up in questions about which inequalities are justified 
and which are not, and it has pursued this through all kinds of hypothetical examples, allowing us to work out whether individual A was entitled to have more than individual B. At its simplest, this may take the form of asking whether an individual who works very much harder than someone else who spends all their time lying on the beach is entitled to more.

But that reduces debates about inequality and equality to comparisons between individuals, whereas I very much agree with Anderson's argument that the issues of inequality that compel us are ones that involve different classes of people assuming power, authority, superiority over others. Restoring the sense that it is group inequalities, social hierarchies and systemic exclusions and discriminations that make us an unequal society is critical.

I do, however, have some concerns about Anderson's argument. There seems to be a mismatch between what she is arguing - much of which is hugely compelling - and the political challenges that face us in Britain in the immediate future. Rightly or wrongly, many people today actually think that the social hierarchies associated with ascriptive group identities have been dealt with. There is a very widespread view that this has somehow been addressed through antidiscrimination legislation, which supposedly provides us with equal pay and equality between the sexes, and laws against racism or incitement of religious and racial hatred. We even have gay marriage. And so for a lot of people, when they look back over the last 20 or 30 years of British politics, their sense is that there have been a lot of advances in terms of those kinds of ascriptive group hierarchies. However, what we have absolutely failed to do is to address income inequalities.

For so many people on the left it has felt as though no one is really addressing the gap between the rich and the poor; the increase in the number of children living in poverty; the absolute decline in real incomes over the last five years (mirroring what has happened in the US for a long time); the reliance on food parcels distributed by charities. Theoretically, I am very much in tune with Professor Anderson in that these are not things to be pitted against one another - it is not as though you focus either on resources or on the power relations and the ways in which people assert their superiority over others. Also, clearly, if you have a society which is very deeply divided between the rich and poor, then that does sustain all kinds of social hierarchy, in terms of contempt for the poor. In recent British politics, in particular, we have seen the demonisation of welfare recipients, who are treated like dirt in the public discourse. It is not that these things are counterposed, but there is a sense that at this particular political juncture, it is encouraging the wrong kinds of initiative to be saying that the distributional questions have been overstated and what we need to talk about are the hierarchies between ascriptive groups.

The issue is not so much a substantive disagreement with what Professor Anderson is saying; instead, I think it is a question of how one enables it to inform what one does in a political context where a lot of people think that the social hierarchies have been dealt with but distributional resource questions remain unaddressed.

"At this particular
political juncture,
it is encouraging
the wrong kinds
of initiative to be
saying that the
distributional
questions have
been overstated
and what we need
to talk about are
the hierarchies
between ascriptive
groups."




\section{REPLY: ELIZABETH ANDERSON}

Stressing the importance of relations of equality does not deny the importance of distributive equality, but instead gives it a certain place in our thinking. In many contexts, equality of distribution is needed to secure a better-functioning democracy, and also to secure equality of dignity, which is perhaps a stronger concern in the UK than in the US, where for cultural reasons stigma has not been so tightly attached to class identity. And equality of distribution is needed to ensure that everyone's interests are really being taken into account by the mainstream institutions of society not just the state but the market as well.

For example, if we look at the history of concerns about distribution, there is this older republican tradition which Ben Jackson alludes to which is very worried about concentrations of wealth at the top. We do know that it is practically a natural law that when you have extreme inequality and enormous wealth concentrated at the top then the wealthy will capture the political process and you get plutocracy. That is highly relevant today: political scientists who have looked at the responsiveness of Congress in the US to different classes of voters ranked by income have discovered that lawmakers essentially ignore the political preferences of everybody except those at the top, because that is where their campaign contributions are coming from.

This links to one of the points that Anne Phillips makes about how there seems to have been genuine progress on some hierarchies, such as sexual orientation. The reason for that is that elites are divided: you have a lot of people in the top 1 per cent who care about gay rights, and so the system responds.

It is absolutely critical for a functioning democracy to avoid this form of plutocracy. There have to be some kind of constraints at the top for purely political democratic reasons; otherwise you simply cannot have a functioning democracy where citizens are truly treated as equals.

Another point to be made about distribution is to ask why income inequality has increased so dramatically. No serious argument can be made that increases in income inequality have been to the benefit of everyone quite the contrary. We have a lot of evidence from the 2008 crash that the increased concentration of wealth is actually shifting a lot of the burden and risks to the rest of the population while the people at the top reap the gains.

The Occupy movement highlighted just this point with its slogan 'we are the 99 per cent'. This is the idea that the system is rigged and that the constitutive rules of a capitalist economy - of banking, finance, bankruptcy and intellectual property - have been systematically rewritten so as to redistribute income to the top at the expense of the rest. Because democratic processes have been captured by the top 1 per cent, the rules have been changed, whether in relation to bankruptcy, credit, access to higher education, tuition charges, intellectual property or access to mortgages.

"Equality of
distribution is
needed to ensure
that everyone's
interests are
really being taken
into account by
the mainstream
institutions of
society - not just
the state but the
market as well."


It is important to focus on the constitutive rules by which these inequalities are produced in the first place. Constitutive rules must be written in such a way that everyone has an interest in them, or else the fundamental equality of standing of individuals has not been respected.

So, my argument is not that we have to choose between distributive and relational concerns, but rather that we should see concerns about distribution as a way of causally thinking through what we have to do in order to achieve a society where individuals relate to each other as equals. Distribution is a very important instrument for realising a society of equals.

Elizabeth Anderson is professor of philosophy and women's studies at the University of Michigan. 